\title{
The Effect of National Standard Education Towards Student's Character at Junior High School and Islamic Junior High School
}

\begin{abstract}
Ishak Aziz
Faculty of Sport Science, Universitas Negeri Padang, Indonesia

"Corresponding author. Email: 60ishakaziz@gmail.com

ABSTRACT

The purpose of this study is to determine how the National Standard Education consisting of Content Standard, Process Standard, Education Staffs Standard, and Assessment Standard influences the character of the students at Junior High School and Islamic Junior High School in Bukittinggi. This is a quantitative research method involving 138 Junior High School students. The instrument used in this research was a questionnaire on characteristics. Data were analyzed using simple regression analysis. Based on the data analysis, it was found that: 1) the Content Standard affects students' characteristic with $t_{\text {calculate }}=3.149$ and $\left.\mathrm{t}_{\mathrm{table}}=2.44,2\right)$ the Process Standard affects students' characteristic with $t_{\text {calculate }}=0.697$ and $t_{\text {table }}=2.44,3$ ) the Educational Staff Standard affects students' characteristic with $t_{\text {calculate }}=1.771$ and $t_{\text {table }}=2.44$, 4) the Assessment Standard affects students' characteristic with $t_{\text {calculate }}=2.516$ and $t_{\text {table }}=2.44,5$ ) the Content Standard, Process Standard, Educational Staff Standard, and Assessmant Standard affects students' characteristic with $t_{\text {calculate }}=1.927$ and $t_{\text {table }}=2.44$. Based on the data analysis, it can be concluded that: (1) there is the effect of the Content Standard on students' characteristics, (2) there is no effect of the Process Standard, Educational Staff Standard, and Assessment Standard on students' characteristics.
\end{abstract}

\section{Keywords: Character, National Standard Education}

\section{INTRODUCTION}

The birth of curriculum 2013 or known as Kurtilas is not separated from the fact that the quality of education in Indonesia is lower than the country which is being a benchmark. So many obstructions in realization this curriculum, although in 2014 all of the equipments that support it has been prepared and distributed to the regency and the city in Indonesian for all education's level. So, there is no reason for the school to do not using this curriculum. From the interview with some students of the various levels of education, there is some information which said that Kurtilas is accommodative and give a space to the students for increase creativity in sociality, psychomotor and cognitive. If associated with the law of education No. 20 year 2003 about national education system which declare that the purpose of education is to increase of student's potential, so the students become a man of faith, and fear of God, have a good personality, healthy, having knowledge, competent, creative, independent, democratic, and have responsibility (MONE, 2003). So that, the curriculum has been designed for the purpose of the education above. In Law No. 20 year 2003 about national education system article 1, paragraph 17 declare that national standard education is the minimum criteria of the education system in Indonesia, and article 1, paragraph 3 explain about national standard education is education system in Indonesia interlinked in an integrated manner to achieve national education goals. Besides, because of the guidance from the Law No. 20 year 2003, in 2005 the birth of government regulation No. 19 year 2005 about national standard education. In chapter 2 , article 2, PP 19 year 2005 explained that "the scope of national standard education include: 1. Standard content, 2. Standard process, 3. Standard competence, 4. Standard teachers and education personnel, 5. Standard facilities and infrastructure, 6. Standard management, 7. Standard financing, 8. Standard assessment of education" [1]. The implementation of this curriculum has the effect to the student's character, so the government through the ministry of education has been launching national standard education mapping [2]. There are 8 standards that have achieve for the school to get the excellent ratings (according to national standard education (SNP)), among others are included standard content, process, teachers and education personnel, and facilities and infrastructure. Standard 
content is about the pattern and the guiding for the teacher which is reflected in the curriculum, where the target or the goal has been cleared in that curriculum. So, it is a standard process, without there is a studying process where the students only will get the knowledge, while the attitude getting less attention. Teachers and education personnel (PTK) is the important thing in achieving the goals in SNP. This was done because it was almost obtained the decade Permendiknas year 2006 and 2007 in some national standards education, it does not give the effect to the student's characters. There are still a lot of students of Junior high school which are smoking during the school hours or hours of rest outside the school, and also there are a lot of students that going to school from the house but do not entered the classroom. Besides that, also there is a brawl between schools or a brawl between the students and the society. Teach the student the habitual ways of thinking and behaving that help individuals to work together as a family, society, and a country. Help them to making responsible decisions. The values contained in the statement above are very rare. The fact today is there are so many young generations who using drugs, doing the brawl and also being the robbers. From all of that facts needed to see the student's character to increase the quality of the education through national standard education (NES). "How is the national standard education influence the student's character at Junior high school and Islamic Junior high school in Bukittinggi?"

The nation successful in raising the goal is not only determined by abundant natural resources, but also determined by the quality of human resources. A great nation can be seen from the quality or the character of the human. Lickona (Dalam Panduan Pelaksanaan Pendidikan Karakter di SMP, 2011) said that a nation is heading the ravine of destruction when the character is pawned. "Character is a behavior, nature, personality psychology and moral which differentiate one and another" [3]. There are some characteristics of a nation which is heading the ravine of destruction: 1) Cheating 2) Plagiarism 3) Copyright 4) The illegal helper of the admission of University 5) Sale and purchase of fake diploma. Education is the main factor in the character building, as "schools are educational institutions which have role and responsibility toward children character building" $[4$

Doing a revolution of the character through realignment of the national education policy by prioritizing aspects of civic education, that puts proportionally educational aspect, such as teaching the history of the formation of the nation, the value of patriotism and love the homeland, the spirit of defending the country in Indonesian education curriculum.

Generally, there are 4 human personalities: 1) Koleris ; this type of personality characterized by the personal who likes independent, assertive, fiery, like challenges, and being the boss on himself, 2) Sanguin ; this type characterized by the human that likes a simple thing, happy and cheerful, like a surprise, very like social acts and having fun, 3) Plegmatis ; the person who including this type likes to being cooperate, avoiding the conflicts, do not like the suddenly changes, a good interlocutor, and likes a definite thing, 4) Melankolis ; this personality likes a detail things, saving anger, perfectionist, likes a clear instruction, and routine activities.

Character is the habituation study of weaknesses, the overcoming weakness and fixing weakness. Therefore, the character is a gift from the God. There are 2 aspects that can be used to see the characters of individual: visible aspect and invisible aspect. Visible capabilities are appearance competence which can be observed directly by the senses of others. Meanwhile invisible capabilities are rational competence which known taksanomi bloom as cognitive, affective, and psychomotor [5]. Basically, human spirit divided into 2 aspects, aspect of ability and aspect of personality. "Aspect of ability covers learning achievement, intelligentsia, and talent. While aspect of personality covers characteristics, self-adjustment, interest, emotion, attitude and motivation" [6]. Early behavior is determining the status of knowledge and skill to get to the future status. Early behavior is one of the characteristic which influence the implementation and the result of the study. According to "early behavior is a knowledge that needs to achieve instructional goals." [7]. So readiness to learn in general is the ability of someone to get the benefit from the experience. While readiness cognition is associated with knowledge, thought, and quality thinking of someone in facing of the new learning situation there 18 characteristic features in character education which can be implementation in learning process: religious, honest, tolerance, discipline, hard worker, creative, independent, democratic, curiosity, nationality, rewarding achievements, friendly/communicative, peace love, like to read, sociality, and responsibility. Based on the development of 18 characteristic features, teachers try to implementing it. So it is hope to help in building a good character of the students.

Education is the main factor in building the character. A good education will be able to lead a nation towards better. The government, especially The Ministry of National Education and local government is required to provide the service and convenience, and also guaranteeing the quality education for each citizen without discrimination. Meanwhile the community is obliged to provide support resources in education. Law No. 22 year 1999 and followed by Law No. 32 year 2004 and also Law No. 23 year 2014 about local government, with the aim of educating the nation. Therefore, the capital government and local 
government as the protector and a life-changing society become much better and guiding people to the new things. It means that individuals jointly introduced on responsibility in a society. Human resources, especially teacher is a learning agent who must have 4 competences; pedagogic, personality, professionalism and sociality (PP RI No: 19 year 2005 article 28). According to PP. No. 74 year 2008, pedagogic competence is the ability of the teacher in management of learning at least the following: a. comprehension insight or the cornerstone of education. $b$. the understanding of the learners. c. the development of the curriculum or syllabus. d. designing defenders. e. implementation of learning that educates and dialogical. f. utilization of learning technologies. g. evaluation of learning process. h. development of learners to actualize various potentials. Meanwhile personality competence is a. faith and fair. b. have a good moral. c. wise and prudent. d. democratic. e. steady. f. commanding. g. stable. h. mature. i. honest. j. sportsmanship. k. become role model for the students and the society, and objectively evaluating its own work. 1. develop themselves independently and sustainably. The next is sociality competence is teacher's ability as a part of the community which has the competence to: a. oral communication, written or gesture politely, b. using communication technology and information functionally, c. effectively interact with the students, fellow educators, leadership education units, the parents of the students, d. associating politely with the community by using the norm and prevailing value system, e. applying the principle of true brotherhood, and $\mathrm{f}$. the spirit of togetherness. Then professionalism competence is the ability of the teacher in mastering knowledge of science, technology, and/or art and culture which is at least cover: a. the subject matter is broad and deep in accordance with the standards of the program content of education unit, or learning subjects; and b. concepts and methodology of scientific disciplines, technology, or relevant art, that is conceptually coherent with a shade or educational unit program, or learning subjects. All of the competences above is expected to produce Indonesian people which is intelligent comprehensive and competitive. It means that spiritual intelligent, emotionally and socially intelligent, intelligent and witty intellectual and aesthetic kinesthetic (RPJPN 2005-2025).

To improved skills, need to set up requirements such as the standardization of achievement. The standard serves as a references design and educational development. Therefore the Ministry of Education and Culture has been issued PP No. 32 year 2013 which stated that the national standard education serve as a basis for planning, implementation and monitoring of education in order to realize the national education quality. National standard education is a high level of similarity with a certain degree of implementation of the national education system. In PP No.32 year 2013 explain that national standard education is the minimum criteria of the education system in Indonesia. So each implementing agency education has to use educational system based on the minimum criteria above. The aim of the national standard education is to ensuring the quality of national education in the framework of educating the nation and formed the character, and also dignified civilization There are 8 standards: a. Standard content, b. Standard process, c. Graduate competence standard, d. Standard teachers and education personnel, e. Standard facilities and infrastructure, f. Standard management, g. Standard financing, h. Standard assessment of education.

After analyzed all of the education standards, it found some standards that effect student's character; standard content, process, teachers and education personnel, and assessment of education. Besides the others standards are more to the preparation of facilities and infrastructure.

Standard content is the scope of material and level of competence as outlined in the criteria of competence graduates, competence study materials, competence studying subjects, and syllabus of learning that must be filled by the learners at a certain level of education, it is explained in the regulation of the national education minister No. 22 year 2006. Standard content is the criteria about the scope of material and level of competence to achieve competence of graduates at a certain level of education. The scope of material formulated based on criteria charge compulsory which determined in accordance with laws and regulations, scientific concept, and characteristics education units and educational programs. For the next, the level of competence formulated based on the criteria from the level of learner's development, competence and qualification Indonesia, and the mastery of tiered competence.

Standard process is intended to assess learning and internalization of the character and also the establishment of competence of learners. In this case the assessment process is conducted to assess the activity, creativity, and the involvement of students in learning, especially the involvement of mental, emotional and social in establishing the competence and character of learners. Standard process is national standard education which related to learner process at elementary school to achieve the graduate competence standard, in Permendikbud No. 65 year 2013 explained that standard process is the criteria about implementation of learning in educational unit to achieve the graduate competence standard. Standard process that developed should refer to graduate competence standard that stated as basic rule in government No. 32 year 2013; the change toward government rule No. 19 year 2005 about national education standard. Therefore every educational unit 
should do learning design in order to do learning and evaluation process to increase efficiency and affectivity of competence.

Standard teachers and education personnel; in this point the researcher make a limit to academic, teacher, headmaster academic competence standard. Teacher is most important actor in school environment, in order to change student's behavior. They have the biggest function and responsibility in learning process inside and outside of the classroom; it is included advisory assignment. It is necessary to have high qualification of competence toward the teachers in order to complete those assignments. Academic qualification, based on national education minister rule No. 16 year 2007 about teacher qualification stated that junior high school teacher should have minimal education academic qualification is bachelor in education study department or psychology that gained into qualified department program.

Competence in Indonesian National Ministry of Education Rule No.16 , 2007 about teacher qualification and competence says; the teacher in order to make some lecture in class he or she should have academic competences such as:

1. Pedagogic competence, teacher should acknowledge students characteristic in some aspects; physical, emotional, social and etc. The teacher should acknowledge learning theory, able to develop the curriculum, able to utilize technology, able to communicate effectively, able to do evaluation toward the lecture and able to do something in order to increase the quality of learning process.

2. Personal competence; teacher should behave and obey appropriate public norms.

3. Social competence; in learning process, teacher should be objective, not to be discriminative, have good communication skills, and have good adaptation ability toward social environment.

4. Professional competence; teacher should acknowledge and practice the teaching structure, material and concept.

Standard assessment; Kemendikbud (2008) in Indonesian national education ministry No. 20 year 2007 explained some factors that is important to know in an assessment; 1) The definition of assessment, 2) The principle of assessment, 3) Technique and instrument of assessment, 4) Mechanism and procedure of assessment, 5) Assessment by educators, 6) Assessment by the education unit, 7) Assessment by the government. Evaluation is data compilation process to determine how far, in what thing, and how to achieve the aim of the education. It is also stated by the Cronbach and Stufflebeam in that evaluation process is not only to measure how far the aim was achieved, but also the result will used to make a decision.
Standard of contend is related with purpose of national education substation into spiritual, knowledge, ability and social behavior domain. This is developed in order to establish framework criteria and basic competence that suitable toward competence of graduate. Standard of process is criteria about learning process in education field to achieve competence of graduate's purpose. Education is process to change behavior to be better one. It is a basic standard that necessary to fulfilled. National Education Standard (Indonesia) about Teacher and Education says teacher has full responsibility in student learning process inside and outside of classroom, it also included as educational advisor. It means that teachers are necessary to have good quality of educational and competence background that suitable with education purpose. The most dominant competence that the teacher should have is pedagogic; teacher should able to acknowledge and applied the educational theory, utilize technology, communicate effectively, develop learning curriculum, and can conduct some action to increase student quality. Standard of Assessment and Evaluation of learning result is an important procedure in education system for both students and teachers in order to achieve learning process purpose as character building.

\section{METHOD}

This article use inferential descriptive methodology. It purposed to acknowledge how far the National Education Standard has make effect toward character building into junior high school student in Bukittinggi. Research populations are every junior high school student in Bukittinggi that counted have 15 schools in total. In order to have research sample, this article use 10 students in every school by using Stratified Random Sampling. This article use some instrument for character as prime date and secondary one is national standard education system that possessed by education and sport government department in Bukittinggi. as data resources. Simple regression by using Spss type 16 is analysis technique in this article.

\section{RESULT}

Based on verification of data, there are 15 Junior High School and 138 samples.

Table 1 Schools list

\begin{tabular}{|c|c|c|c|}
\hline No & School Name & Sample & $\begin{array}{c}\text { Approved } \\
\text { Sample }\end{array}$ \\
\hline 1 & SMPN 1 & 10 & 10 \\
\hline 2 & SMPN 2 & 10 & 10 \\
\hline 3 & SMPN 3 & 10 & 8 \\
\hline 4 & SMPN 4 & 10 & 10 \\
\hline 5 & SMPN 5 & 10 & 9 \\
\hline 6 & SMPN 6 & 10 & 9 \\
\hline
\end{tabular}




\begin{tabular}{|c|c|c|c|}
\hline 7 & SMPN 7 & 10 & 10 \\
\hline 8 & SMPN 8 & 10 & 10 \\
\hline 9 & SMPS XAVERIUS & 10 & 10 \\
\hline 10 & SMPS PSM & 10 & 10 \\
\hline 11 & SMP AL ISLAH & 10 & 10 \\
\hline 12 & MTsN 1 & 10 & 10 \\
\hline 13 & $\begin{array}{c}\text { MTs } \\
\text { BAITURRUDWAH }\end{array}$ & 8 & 8 \\
\hline 14 & MTs AL MA'RIF & 8 & 8 \\
\hline 15 & $\begin{array}{c}\text { MTs M. } \\
\text { MUNAWARAH }\end{array}$ & 4 & 4 \\
\hline & SAMPLE & 140 & 138 \\
\hline
\end{tabular}

\section{CONCLUSION}

According to data analysis for national standard education, standard content toward student's character at Junior high school in Bukittinggi, can be explained that $F_{h}$ with a significance level 0,05 with sample n$1=137$ obtained for 3,149 besides Ft is about 2,44 . Thus it can be stated that there is an effect of national standard education toward student's character at Junior high school and Islamic Junior high school in Bukittinggi.

According to data analysis for national standard education, standard process toward student's character at Junior high school in Bukittinggi, can be explained that $F_{h}$ with a significance level 0,05 with sample n$1=137$ obtained for 0,697 besides Ft is about 2,44. So, it can be stated that there is no effect of national standard education toward student's character at Junior high school and Islamic Junior high school in Bukittinggi.

According to data analysis for national standard education, teachers and education personnel toward student's character at Junior high school in Bukittinggi, can be explained that $F_{h}$ with a significance level 0,05 with sample $\mathrm{n}-1=137$ obtained for 1,771 besides $\mathrm{Ft}$ is about 2,44. It can be stated that there is no effect of national standard education toward student's character at Junior high school and Islamic Junior high school in Bukittinggi.

According to data analysis for national standard education, standard assessment toward student's character at Junior high school in Bukittinggi, can be explained that $F_{h}$ with a significance level 0,05 with sample $n-1=137$ obtained for 2,516 besides $\mathrm{Ft}$ is about 2,44 . It can be conclude that there is an effect of national standard education toward student's character at Junior high school and Islamic Junior high school in Bukittinggi.

1) Based on the analysis of national standard education toward student's character, can be conclude that $F_{h}$ with a significance level 0,05 with sample $\mathrm{n}-\mathrm{k}$ $-1=134$ obtainable 1,927 meanwhile $\mathrm{Ft}$ is about 2,44. So, there is no effect of national standard (SNP) content, process, teachers and education personnel, and also the assessment toward student's character at Junior high school and Islamic Junior high school in Bukittinggi.

\section{REFERENCESS}

[1] Kemendiknas, "Undang-Undang RI No 20 Tahun 2003 Tentang Sistim Pendidikan Nasional," Jakarta; Kemendiknas. 2005

[2] Kemendikbud, "Peraturan Pemerintah No. 32 Tahun 2013 tentang Perubahan Standar Nasional Pendidikan," Jakarta; Kemendikbud. 2013

[3] https://id.wikipedia.org/wiki/Karakter. 03 Januari. 2016.

[4] Anwar, Hendarman, "Penguatan Pendidikan Karakter," Jakarta; Kementerian Pendidikan dan kebudayaan RI, pp, 108-170. 2016.

[5] Djaali, "Psikologi Pendidikan," Jakarta; Bumi Aksara, pp, 44-60. 2008.

[6] Gulo, W, "Strategi Belajar Mengajar," Jakarta; PT Gramedia Widiasarana. 2002.

[7] Winkel, W.S, "Psikologi Pengajaran," Yogyakarta; Media Abadi. 2007. 